Jurnal Interpretasi Hukum |ISSN: 2746-5047

Vol. 2, No. 2 - Agustus 2021, Hal. 334-338| Tersedia online di

https://www.ejournal.warmadewa.ac.id/index.php/juinhum

DOI: https://doi.org/10.22225/juinhum.2.2.3437.334-338

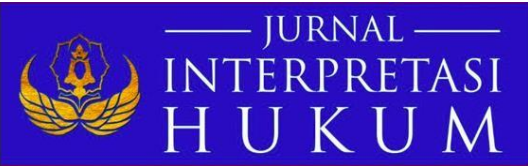

\title{
TANGGUNG JAWAB DEBITUR DALAM PERJANJIAN KREDIT TANPA AGUNAN (KTA) PADA KOPERASI SERBA USAHA (KSU) KUTA MIMBA KABUPATEN BADUNG
}

\author{
Dewa Ayu Putu Mita Purnamasari, I Nyoman Putu Budiartha, Desak Gde Dwi Arini \\ Fakultas Hukum Universitas Warmadewa, Denpasar, Bali \\ mitadewaayu49@gmail.com, budiarthaputu59@gmail.com, arinidesak1966@gmail.com
}

\begin{abstract}
Abstrak
Fasilitas kredit tanpa agunan (KTA) pada Koperasi Serba Usaha (KSU) Kuta Mimba Kabupaten Badung dapat meringankan beban masyarakat yang ingin berwirausaha, karena tanpa adanya jaminan kebendaan. Tujuan dari penelitian ini untuk mengetahui pengaturan jika debitur dinyatakan wanprestasi pada Koperasi Serba Usaha (KSU) Kuta Mimba Kabupaten Badung serta mengatahui tanggung jawab debitur dalam perjanjian kredit tanpa agunan (KTA) pada Koperasi Serba Usaha (KSU) Kuta Mimba Kabupaten Badung. Penelitian ini dilakukan di KSU Kuta Mimba di Kabupaten Badung, Tipe penelitian ini menggunakan penelitian hukum empiris yaitu pendekatan permasalahan yang dilihat dari segi aturan-aturan hukum dengan kenyataan-kenyataan yang ada di lapangan. Hasil penelitian yang diperoleh pengaturan jika debitur dinyatakan wanprestasi diatur dalam Perjanjian Pinjaman pasal 6 dan 7 yang mengatur mengenai hak dan kewajiban penerima pinjaman dan pemberi pinjaman. Tanggung jawab kreditur kepada debitur dalam perjanjian kredit tanpa agunan (KTA) adalah yang pertama dilakukan dengan mendatangi debitur ke rumah dengan tujuan menanyakan apa yang menjadi penyebab tidak membayar kredit, yang kedua melakukan dengan penjadwalan ulang.
\end{abstract}

Kata kunci: Koperasi serba Usaha Kuta Mimba, Tanggung Jawab Debitur, Perjanjian Kredit Tanpa Agunan.

\begin{abstract}
Unsecured credit facilities (KTA) at the Kuta Mimba Business Multipurpose Cooperative (KSU) in Badung Regency can ease the burden on people who want to be entrepreneurs, because there is no material guarantee. The purpose of this study is to determine the arrangement if the debtor is declared in default at the Multipurpose Business Cooperative (KSU) Kuta Mimba, Badung Regency and to know the debtor's responsibilities in the unsecured credit agreement (KTA) at the Multipurpose Business Cooperative (KSU) Kuta Mimba, Badung Regency. This research was conducted at KSU Kuta Mimba in Badung Regency. This type of research uses empirical legal research, namely a problem approach that is seen in terms of legal rules with the realities that exist in the field. The results of the research obtained that the arrangement if the debtor is declared in default is regulated in the Loan Agreement articles 6 and 7 which regulate the rights and obligations of the borrower and the lender. The responsibility of the creditor to the debtor in the unsecured credit agreement (KTA) is first done by visiting the debtor to the house with the aim of asking what is the reason for not paying the credit, the second is doing by rescheduling.
\end{abstract}

Keywords: Legal Responsibility of Debitors, Unsecured Credit, Kuta Mimba Multipurpose Cooperative

\section{PENDAHULUAN}

Indonesia merupakan negara hukum artinya segala tindakan yang dilakukan oleh masyarakat Indonesia harus berdasarkan atas hukum yang berlaku di negara Indonesia. Indonesia memiliki paham kehidupan berbangsa dan bernegara yaitu paham kebersamaan dengan hubungan antara warga negara berdasarkan atas asas kekeluargaan (Elli Ruslina, 2013).

Pasal 33 Undang-Undang Dasar Negara Republik Indonesia Tahun 1945 merupakan pesan moral dan pesan budaya dalam konstitusi Republik Indonesia di bidang kehidupan ekonomi (Bagir Manan, 1995). Pesan konstitusianal tersebut tampak jelas, bahwa yang dituju adalah suatu sistem ekonomi berdasar kebersamaan dan berdasar atas asas kekeluargaan (Herman Soewardi, 1985). Contoh paling ideal usaha bersama berdasar atas asas kekeluargaan adalah koperasi, Koperasi merupakan badan usaha yang beranggotakan orang-seorang atau badan hukum Koperasi dengan melandaskan kegiatannya berdasarkan prinsip Koperasi sekaligus sebagai gerakan ekonomi rakyat yang berdasar atas asas kekeluargaan sebagaimana telah dibuat dan disahkan dalam Undang-Undang Nomor 25 Tahun 1992 Tentang Perkoperasian (Mohammad Hatta, 1981). 
Manusia dalam kehidupan sehari-hari memiliki kebutuhan yang beraneka ragam dan selalu ingin memenuhi kebutuhan yang diinginkannya. (Gatot Supramono, 2013) Untuk memenuhi kebutuhan tersebut, manusia harus berusaha dengan cara bekerja keras contohnya dengan cara membuka usaha sendiri atau berwirausaha. Untuk berwirausaha tentunya diperlukan modal. Untuk mendapatkan modal tersebut dapat dicapai dengan cara berhutang kepada pihak koperasi. Namun kepalanya saat seseorang yang ingin berwirausaha ketika ingin berhutang kepada koperasi tapi tidak memiliki aset untuk dijadikan agunan untuk pinjaman yang akan diperoleh dari koperasi. Untuk mengatasi masalah tersebut, dapat menggunakan fasilitas kredit tanpa agunan (KTA).

Pemberian kredit tanpa agunan oleh koperasi ini dapat meringankan beban masyarakat, karena kredit yang diberikan koperasi tanpa adanya jaminan kebendaan, yang selama ini menjadi kendala bagi masyarakat golongan ekonomi rendah. Koperasi Serba Usaha (KSU) Kuta Mimba Kabupaten Badung atau yang sering disebut dengan KSU Kuta Mimba memiliki salah satu produk yakni kredit tanpa agunan (KTA). Kredit tanpa agunan ini merupakan kredit yang diberikan tanpa adanya jaminan kebendaan dan kredit yang diberikan sebesar Rp. 5.000.000,00 dengan jangka waktu biasanya 24 bulan atau 2 tahun saja, hal ini menjadi salah satu alternatif perkreditan bagi calon wirausaha yang baru memulai usahanya karena tidak ada diperlukannya jaminan kebendaan.

Namun dalam pelaksanaannya, kredit tanpa agunan yang diberikan oleh KSU Kuta Mimba ini tidak selalu berjalan dengan baik atau lancar sesuai dengan apa yang telah dituangkan dalam perjanjian pinjaman, Sehingga seringkali timbul permasalahan atau pelanggaran dalam perjanjian kredit tanpa anggunan oleh debitur. Jumlah Penyaluran Kredit KSU Kuta Mimba Dari Tahun 2018 sampai dengan tahun 2020.

\begin{tabular}{|l|l|l|l|}
\hline Nomor / Jenis Kredit & Tahun 2018 & Tahun 2019 & $\begin{array}{l}\text { Bulan Januari s/d } \\
\text { September 2020 }\end{array}$ \\
\hline 1. Kredit & 986 & 827 & 837 \\
\hline 2.Kredit Tanpa Agunan & 146 & 125 & 64 \\
\hline 3.Kredit Macet Tanpa Agunan & 0 & 0 & 15 \\
\hline
\end{tabular}

Tabel 1.1 Sumber Data KSU Kuta Mimba

Berdasarkan observasi awal di KSU Kuta Mimba terdapat 968 kredit pada tahun 2018, 827 kredit pada tahun 2019 dan dari bulan Januari sampai dengan bulan September terdapat 837 kredit. Yang menggunakan fasilitas kredit tanpa agunan hanya berkisar 15\% nya saja yakni di tahun 2018 sebanyak 146, tahun 2019 sebanyak 125, dan pada bulan Januari sampai dengan September 2020 sebanyak 64. Pada tahun 2018 dan 2019 tidak adanya kredit tanpa agunan yang macet namun kasus kredit tanpa agunan macet mulai muncul sejak awal tahun 2020 ini yakni sebanyak 15 kredit macet. Yang melatarbelakangi terjadinya kredit macet yakni ketidaksanggupan menerima pinjaman untuk mengembalikan utang pokok dan bunga pada KSU Kuta Mimba.

Ni Made Arin (2017) berpendapat bahwa pembangunan ekonomi di Indonesia menempatkan UMKM selalu digambarkan sebagai sektor yang mempunyai peranan yang penting, karena sebagian besar jumlah penduduknya berpendidikan rendah dan hidup dalam kegiatan usaha kecil baik disektor tradisional maupun modern. Namun demikian, usaha pengembangan yang telah dilaksanakan masih belum memuaskan hasilnya, karena pada kenyataannya kemajuan UMKM sangat kecil dibandingkan kemajuan yang dicapai usaha besar. Perjanjian kredit yaitu ikatan antara debitur (berhutang) dengan kreditur (pemberi hutang) yang menimbulkan hak dan kewajiban kepada para pihak yang terkait, yang mana perjanjian ini biasanya diikuti dengan perjanjian (jaminan penanggung), (Sang Ayu Kadek Wiesma Dewintha \& Ni Putu Purwanti, 2019). Munculnya fasilitas kredit tanpa agunan (KTA) ini merupakan suatu aliernatif yang menarik bagi pengusaha karena pada saat ini memang sulit didapat dana rupiah untuk jangka waktu menengah dan panjang. Sementara itu, melalui kredit tanpa agunan (KTA) mereka (pengusaha) dan juga perseorangan dapat memperoleh dana untuk membiayai pembelian barang barang modal atau juga untuk kegiatan konsumsi dengan jangka pengembalian antara 1 tahun hingga 3 tahun (atau hingga 5 tahun) dengan persyaratan yang ringan (Lambang Iswandi, 2019).

Terkait dengan latar belakang diatas, maka mendapatkan tujuan dari penelitian ini adalah untuk mengetahui pengaturan jika debitur dinyatakan wanprestasi pada Koperasi Serba Usaha (KSU) 
Kuta Mimba Kabupaten Badung dan untuk mengetahui tanggung jawab debitur dalam perjanjian kredit tanpa agunan (KTA) pada Koperasi Serba Usaha (KSU) Kuta Mimba Kabupaten Badung.

\section{METODE PENELITIAN}

Berdasarkan judul dan pemaparan yang dijelaskan diatas maka skripsi ini menggunakan tipe penelitian ini menggunakan penelitian hukum empiris. Penelitian hukum empiris yaitu pendekatan permasalahan yang dilihat dari segi aturan-aturan hukum dengan kenyataan-kenyataan yang ada di lapangan, yang kemudian dikaitkan dengan adanya gejala-gejala hukum yang ada didalam kehidupan masyarakat. Pendekatan yang digunakan dalam penelitian ini Pendekatan Perundang-undangan, yaitu pendekatan masalah yang didasarkan teori hukum serta peraturan perundang-undangan yang berlaku sesuai dengan permasalahan yang akan dibahas pada penelitian ini, dan Pendekatan Sosiologis, yaitu pendekatan yang didasarkan pada fakta-fakta yang terjadi di lapangan yang berkaitan dengan permasalahan dalam penelitian ini. Adapun sumber data yang digunakan dalam penelitian ini, yaitu sumber data primer dan sumber data sekunder. Sumber data primer merupakan data yang diperoleh dari sumbernya secara langsung atau diperoleh dari penelitian lapangan dilakukan melalui wawancara atau interview. Dalam hal ini pengumpulan data diperoleh melalui hasil wawancara dengan para pengurus di KSU Kuta Mimba di Kabupaten Badung dan sumber data sekunder adalah data yang diperoleh dari studi kepustakaan. Untuk lokasi penelitian pada KSU Kuta Mimba di Jalan Sriwijaya Nomor 18, Kelurahan Legian, Kecamatan Kuta, Kabupaten Badung dengan cara menggunakan teknik pengumpulan data melalui wawancara dan studi pustaka.

\section{HASIL PENELITIAN DAN PEMBAHASAN}

\section{Pengaturan Jika Debitur Dinyatakan Wanprestasi Pada Koperasi Serba Usaha (KSU) Kuta Mimba Kabupaten Badung.}

Atas ketentuan Pasal 1238 KUHPerdata, debitur dianggap telah melakukan wanprestasi apabila lalai dalam melaksanakan kewajiban lewat dari waktu yang telah ditentukan dan apabila dalam perjanjian tidak ditentukan batas waktunya, maka diperlukan adanya surat peringatan dari kreditur kepada debitur untuk menyatakan bahwa debitur telah melakukan wanprestasi.

Wanprestasi dilakukan oleh debitur dikarenakan 2 kemungkinan, yakni: (Abdul Kadir Muhammad, 2000) Karena keadaan memaksa atau overmacht, sehingga diluar kekuasaan debitur Karena kesalahan debitur, baik sengaja maupun karena kelalaiannya. Dalam hukum wanprestasi, dapat dilihat pada Pasal 1238 dan Pasal 1243 KUHPerdata. Berikut merupakan bentuk-bentuk wanprestasi. Sedangkan menurut Subekti (2002) bentuk-bentuk wanprestasi yakni sama sekali tidak memenuhi prestasi, prestasi yang dilakukan tida sempurna Terlambat memenuhi prestasi Melakukan apa yang dalam perjanjian dilarang untuk dilakukan.

Syarat debitur melakukan wanprestasi pada KSU Kuta Mimba yakni jika penerima pinjaman tidak dapat membayar angsuran sesuai dengan jangka waktu pinjaman atau telah melawati tanggal pembayaran, sebagaimana tercantumkan pada Pasal 2 Perjanjian Pinjaman yang telah ditandatangani oleh penerima pinjaman dan pemberi pinjaman.

(Berdasarkan hasil wawancara dengan Kepala Bagian Kredit Ibu Ni Ketut Tantri pada tanggal 06 November 2020) Pengaturan wanprestasi pada KSU Kuta Mimba diatur dalam Perjanjian Pinjaman pasal 6 dan 7 yang mengatur mengenai hak dan kewajiban peneima pinjaman dan pemberi pinjaman. Karena setiap pasal yang tercantum pada Perjanjian Pinjaman tersebut telah disepakati oleh penerima pinjaman dan pemberi pinjaman dan menjadi dasar bagi penerima pinjaman dan pemberi pinjaman dalam bertindak. (Berdasarkan hasil wawancara dengan Kepala bagian Kredit Ibu Ni Ketut Tantri pada tanggal 04 November 2020).

Dalam hal ini pemberi pinjaman dan penerima mempunya hak dan kewajiban yang harus dilaksanakan sesuai dengan isi dari perjanjian pinjaman yakni pemberi pinjaman Hak pemberi pinjaman: Pemberi pinjaman berhak menuntut pemenuhan suatu dari penerima pinjaman sesuai dengan yang tercantum dalam perjanjian kredit dan telah disepakatii oleh kedua belah pihak. Pemberi pinjaman berhak menagih denda sebesar 4\% (empat) persen dari jumlah angsuran setiap bulannya jika debitur lalai memenuhi pembayaran yang harus dibayar.

Kewajiban pemberi pinjaman Pemberi pinjaman wajib menyerahkan uang yang di pinjamkan kepada penerima pinjaman setelah perjanjian kredit telah ditanda-tangani oleh pemberi pinjaman dan penerima pinjaman.vPenerima pinjaman berhak menerima pinjaman sejumlah uang dari pemberi 
pinjaman yang sebelumnya telah disepakati besarnya antara kedua belah pihak.Penerima pinjaman wajib mengembalikan utang dalam jumlah yang sama disertai dengan pembayaran bunga yang telah diperjanjikan, dalam jangka waktu yang telah ditentukan. Penerima pinjaman wajib membayar angsuran pokok dan bunganya sebesar $1.5 \%$ (satu koma lima persen) setiap bulannya, jika penerima pinjaman tidak membayar hutang tepat waktu setiap bulannya maka debitur diwajibkan untuk membayar denda sebesar $4 \%$ (empat persen) perbulan.

Penerima pinjaman diwajibkan untuk menyerahkan harta atau kekayaannya jika sudah tidak mampu membayar utang, bunga dan denda serta diwajibkan member harta atau kekayaan yang lain jika tidak cukup untuk menutupi utangnya tersebut.

\section{Tanggung Jawab Debitur Dalam Perjanjian Kredit Tanpa Agunan (KTA) Pada Koperasi Serba Usaha (KSU) Kuta Mimba Kabupaten Badung}

Setiap kredit yang bermasalah maka koperasi akan berupaya untuk menyelamatkan kredit dengan cara rescheduling (penjadwalan kembali) yaitu suatu upaya hukum untuk melakukan perubahan terhadap beberapa syarat perjanjian kredit yang berkenaan dengan jadwal pembayaran kembali/jangka waktu kredit termasuk tenggang (grace period), termasuk perubahan jumlah angsuran. Bila perlu dengan penambahan kredit.

Melalui reconditioning (persyaratan kembali), yaitu melakukan perubahan atas sebagian atau seluruh persyaratan perjanjian, yang tidak terbatas hanya kepada perubahan jadwal angsuran, dan/atau jangka waktu kredit saja. Tetapi perubahan kredit tersebut tanpa memberikan tambahan kredit atau tanpa melakukan konversi atas seluruh atau sebagian dari kredit menjadi equity perusahaan.

Restructuring (penataan kembali), yaitu upaya berupa melakukan perubahan syarat syarat perjanjian kredit berupa pemberian tambahan kredit, atau melakukan konversi atas seluruh atau sebagian kredit menjadi perusahaan, yang dilakukan dengan atau tanpa rescheduling dan/atau reconditioning. Namun yang paling sering digunakan untuk menangani kredit macet yaitu rescheduling (penjadwalan kembali) dengan tujuan utama untuk memperpanjang jangka waktu jatuh tempo pembiayaan tanpa mengubah sisa kewajiban nasabah yang harus dibayarkan kepada bank. Jumlah pembayaran angsuran nasabah menjadi lebih ringan karena jumlahnya diperkecil dari angsuran sebelumnya. (Berdasarkan hasil wawancara dengan Kepala Bagian Kredit Ibu Ni wayan Tantri pada tanggal 12 November 2020).

Adapun tujuan dari penjadwalan ulang yaitu untukenghindarkan kerugian yang berlebihan bagi koperasi karena harus menjaga kualitas kredit yang telah diberikan. Membantu memperingankan kewajiban debitur sehingga dengan keringanan ini debitur mempunyai kemampuan untuk melanjutkan kembali usahanya dan dengan menghidupkan kembali usahanya akan memperoleh pendapatan yang sebagian dapat digunakan untuk membayar hutangnya dan sebagian bias untuk melanjutkan kegiatan usahanya.

Dengan penyelamatan kredit maka penyelesaian kredit bermasalah melalui lembaga-lembaga hukum dapat dihindarkan karena penyelesaian melalui lembaga hukum dalam prakteknya memerlukan waktu, biaya dan tenaga yang tidak sedikit. Dalam tindakan persuasif telah disepakati bersama antara penerima pinjaman dan pemberi pinjaman KSU Kuta Mimba telah bekerja sama dengan asuransi jamkrida (Jaminan Kesehatan Daerah) karena sejak awal pencairan kredit oleh kreditur, secara otomatis debitur harus masuk asuransi jamkrida yang hanya melakukan bayaran diawal saja sebesar Rp. 138.000,00. Besarnya pembayaran asuransi jamkrida ini tergantung jangka waktu pengembalian kredit oleh penerima pinjaman. Hal ini karena KSU Kuta Mimba melakukan kerja sama dengan JKD Bali dalam menangani masalah kredit yang macet. Dan mengenai pembayaran angsuran pokok dan bunganya langsung didebet dari SISUKOP (Simpanan Sukarela Koperasi) yang bisa dilakukan dengan cara menabung setiap harinya. (Berdasarkan hasil wawancara dengan Ketua KSU Kuta Mimba pada tanggal 12 November 2020).

Pada dasarnya asuransi jamkrida hanya bertanggung jawab atas 75\% (tujuh puluh lima persen) dari seluruh jumlah hutang debitur, jika mencukupi maka hutang debitur dianggap lunas tapi jika masih kurang maka kreditur berhak menyita harta benda yang dimiliki oleh debitur untuk mengcover seluruhnya sebagaimana yang telah tercantum pada pasal 7 dalam perjanjian pinjaman pada KSU Kuta Mimba. Namun misalnya debitur meninggal dunia dan sisa hutang debitur masih ada maka para ahli waris tidak diharuskan untuk membayar sisa hutang yang dimiliki oleh debitur, karena asuransi jamkrida tersebut akan bertanggung jawab 100\% (seratus persen) dari seluruh hutang yang harus 
dibayar oleh debitur tersebut. Penagihan secara langsung ini dilakukan KSU Kuta Mimba langsung kepada debitur sampai batas yang telah ditentukan sebanyak tiga kali berturut-turut. Setelah dilakukan penagihan secara langsung tetap tidak membuahkan hasil, maka tindakan tersebut digunakan oleh koperasi selaku pemberi pinjaman sebagai alat bukti dalam membuat laporan kepada pihak kepolisian untuk dilakukan pemanggilan paksa. (Berdasarkan hasil wawancara dengan Ketua KSU Kuta Mimba pada tanggal 12 November 2020).

\section{SIMPULAN DAN SARAN}

\section{Simpulan}

Dari tulisan yang telah diuraikan diatas, dapat ditarik sebuah kesimpulan yaitu pengaturan jika debitur dinyatakan wanprestasi pada koperasi serba usaha (KSU) kuta mimba di Kabupaten Badung ialah sebagaimana pengaturan wanprestasi pada KSU Kuta Mimba diatur dalam Perjanjian Pinjaman pasal 6 dan 7 yang mengatur mengenai hak dan kewajiban penerima pinjaman dan pemberi pinjaman. Tanggung jawab debitur dalam perjanjian kredit tanpa agunan (KTA) pada koperasi serba usaha (KSU) kuta mimba Kabupaten Badung adalah yang pertama dilakukan dengan mendatangi debitur ke rumah, kedua melakukan penjadwalan ulang yaitu penetapan kembali jangka waktu kredit. Jika selama penjadwalan ulang kredit tersebut debitur tetap tidak bisa membayar kewajibannya selama 3 (tiga) kali berturut turut maka secara tidak langsung debitur dinyatakan wanprestasi. Asuransi jamkrida hanya bertanggung jawab atas $75 \%$ (tujuh puluh lima persen) dari seluruh jumlah hutang debitur, jika mencukupi maka hutang debitur dianggap lunas tapi jika masih kurang maka kreditur berhak menyita harta benda yang dimiliki oleh debitur untuk mengcover seluruhnya sebagaimana yang telah tercantum pada pasal 7 dalam perjanjian kredit pada KSU Kuta Mimba.

\section{Saran}

Dari hasil paparan dan simpulan penelitian, peneliti memberikan saran dengan adanya kredit tanpa agunan ini sebaiknya pemerintah (Bidang Perkoperasian) segera mengeluarkan Rancangan UndangUndang mengenai kredit tanpa agunan agar para debitur dan kreditur mempunyai pegangan pasti mengenai hal dan kewajibannya. Semakin banyak bentuk-bentuk wanprestasi yang dapat dilakukan oleh para pihak mengingat segala kemungkinan yang dapat terjadi. Maka diharapkan dalam melakukan perjanjian para pihak tela mengantisipasi segala kemungkinan yang akan muncul dalam perjanjian dan pihak KSU Kuta Mimba harus melakukan penilaian dengan seksama kepada calon debitur dengan menerapkan prinsip $5 \mathrm{C}$. Dalam hal ini mempertemukan kedua belah pihak yang berperkara memberikan solusi atau pemecahan masalah dengan adil dan bijaksana antara debitur dan kreditur.

\section{DAFTAR PUSTAKA}

Arin, N. M. (2017). Penyelesaian Permasalahan Kredit Tanpa Agunan (Umkm) Di Denpasar. Acta Comitas, Vol 1, 122-127.

Dewintha, S. A. K. W., \& Purwanti, N. P. (2019). Tanggung Jawab Penanggung Kepada Debitur Wanprestasi dalam Hal Terjadi Kredit Macet. Kertha Semaya, Vol 7(5).

Hatta, M. (1981). Pengertian Pancasila. PT. Inti Idayu Press. Jakarta.

Kadir, M. A. (2000). Hukum Perdata Indonesia. Citra Aditya Bakti. Bandung.

Manan, B., Magnar, H. K., \& H, M. (1995). Pertumbuhan dan Perkembangan Konstitusi Suatu Negara. Mandar Maju. Bandung.

Ruslina, E. (1945). Dasar Perekonomian Indonesia Dalam Penyimpanan Mandat Konstitusi UUD Negara Tahun 1945. Media. Jakarta.

Soewardi, H. (1985). Koperasi (Suatu Kumpulan Makalah). Ikopin. Bandung.

Siswandi, L. (2019). Kreditur Dan Debitur Dengan Hak Perlindungan Hukum Dalam Perjanjian Kredit Tanpa Agunan. Ilmu Hukum, Vol 15(1).

Subekti. (2002). Hukum Perjanjian (Cet. 22). Intermasa. Jakarta.

Supramono, G. (2013). Perjanjian Utang Piutang. Kencana Prenamedia Grup. Jakarta. 